\title{
UPAYA MENINGKATKAN AKTIVITAS DAN HASIL BELAJAR AGAMA HINDU KELAS IV SD NEGERI 7 MATARAM DENGAN MODEL INQUIRI SEMESTER SATU TAHUN PELAJARAN 2018/2019
}

\author{
Desak Made Ratna Dewi \\ Guru Agama Hindu Kelas IV SD Negeri 7 Mataram
}

\begin{abstract}
Abstrak. Penelitian ini bertujuan untuk mengetahui efektifitas penerapan pendekatan Saintifik model Pembelajaran Inquiri dalam upaya meningkatkan aktivitas dan hasil belajar Agama Hindu Peserta didik Kelas IV SD Negeri 7 Mataram. Manfaat penelitian ini adalah mendorong peserta didik untuk mengembangkan ketrampilan belajar dalam kelompok (kognitif) dan bersosiolisasi dengan teman dalam proses pembelajaran di kelas senyatanya. Dan bagi guru meningkatkan pengembangan pendekatan dan model pembelajaran dengan penerapan saintifik Model Pembelajaran Inquiri dalam pembelajaran kerja kelompok (kooperatif). Penelitian ini dilaksanakan dua siklus, masing-masing siklus kegiatannya adalah; perencanaan, pelaksanaan, observasi dan refleksi. Hasil akhir tindakan pada siklus II menunjukkan bahwa hasil observasi guru pada pertemuan kedua memperoleh skor rata-rata $(4,57)$ dan hasil observasi Peserta didik pertemuan kedua mencapai skor rata-rata $(4,63)$. Sedangkan hasil belajar Peserta didik mencapai nilai rata-rata $(80,00)$, artinya indicator keberhasilan $(\geq 4,0)$ dan hasil belajar $(\geq 75,00)$ telah terlampaui. Karena indicator keberhasilan telah terbukti penelitian dinyatakan berhasil dan dihentikan pada siklus II.
\end{abstract}

\section{Kata Kunci : Motivasi dan hasil Belajar-Model Pembelajaran Inquiri.}

\section{PENDAHULUAN}

Proses pembelajaran di SD Negeri 7 Mataram khususnya pada mata pelajaran Agama Hindu yang berlaku selama ini masih cenderung mengarah pada guru yang aktif menjelaskan materi pelajaran dengan berapiapi tanpa memperdulikan kondisi peserta didiknya.Proses pembelajaran semacam ini telah melahirkan peserta didik yang pasif, kurang kreatif, kurang aktif dalam mengingat pelajaran Agama Hindu sehingga prosentase keberhasilan pada peserta didik sangat memprihatinkan dan berdampak pada rendahnya tingkat kepercayaan peserta didik terhadap guru Agama Hindu dalam proses pembelajaran di kelas senyatanya.

Kondisi nyata yang terjadi pada peserta didik kelas IV SD Negeri 7 Mataram adalah sebagai berikut: 1) peserta didik di kelas IV ini merupakan penyebaran dari sekolahsekolah yang kualitasnya rendah, 2) peserta didik yang pada saat proses pembelajaran kurang aktif dan cenderung bermain-main, saling lempar buku, keluar masuk kelas tanpa izin, 3) peserta didik yang aktivitas belajarnya rendah dan pada saat diadakan ulangan harian memperoleh nilai rata-rata di bawah KKM. Kondisi sebagaimana tersebut diatas dialami pula pada proses pembelajaran mata pelajaran Agama Hindu. Selama proses pembelajaran peserta didik cenderung tidak peduli terhadap apa yang disampaikan oleh guru mata pelajaran. Ketika guru meminta kepada peserta didik untuk bertanya terhadap materi pelajaran yang disajikan, jika ternyata belum faham, belum mengerti, atau tidak tahu sama sekali semuanya diam, ketika peserta didik di berikan tugas secara berkelompok hanya beberapa orang peserta didik saja yang aktif. Ketika masing-masing kelompok disuruh maju untuk mempresentasikan hasil kerja kelompoknya cenderung tidak bersedia bahkan masing-masing anggota kelompok saling tunjuk dan tidak ada hasilnya.

Faktor penyebab terjadinya situasi kelas yang sangat kurang kondusif dalam proses pembelajaran tersebut adalah berasal dari guru itu sendiri maupun berasal dari peserta didik. Selama ini guru Agama Hindu mengajar cenderung mendominasi dengan gaya ceramah yang berapi-api tanpa memperdulikan kondisi peserta didik. Guru 
Agama Hindu sekaligus sebagai peneliti sebenarnya sudah menerapkan pendekatan saintifik sebagaimana yang tertera pada Permen 81 A Tahun 2013 tentang kurikulum 2013, tetapi masih belum optimal dan belum sesuai dengan harapan. Sementara penyebab dari peserta adalah rendahnya kompetensi yang dimiliki serta kurang gairah dalam mengikuti pelajaran Agama Hindu. Apapun yang ditugaskan oleh guru, peserta didik nampak cuek dan tidak peduli akan akibat yang akan terjadi pada dirinya.

Banyak solusi yang bisa dilakukan oleh peneliti, tetapi yang dianggap mampu meningkatkan aktivitas dan hasil belajar peserta didik kelas IV mata pelajaran Agama Hindu yaitu dengan mengoptimalkan pendekatan "saintifik" dengan menggunakan Model pembelajaran Inquiri. Pendekatan saintifik ini memiliki keunggulan bila di bandingkan dengan pendekatan yang lain karena proses pembelajaran terdiri atas lima pengalaman belajar pokok yaitu; a) mengamati, b) menanya, c) mengumpulkan informasi, d) mengasosiasi, dan e) mengkomunikasikan. Dalam pengembangan kegiatan pembelajar dengan pendekatan saintifik ini dirancang sebagai berikut; 1) kegiatan pembelajaran disusun untuk dapat melaksanakan proses pembelajaran secara professional, 2) kegiatan pembelajaran memuat rangkaian kegiatan manajerial yang dilakukan guru agar peserta didik dapat melakukan kegiatan seperti di silabus, 3) kegiatan pembelajaran untuk setiap pertemuan merupakan skenario/langkahlangkah guru agar peserta didik aktif belajar. Kegiatan ini diorganisasikan menjadi kegiatan: pendahuluan, inti dan penutup.

Untuk membuktikan bahwa pendekatan saintifik model pembelajaran Inquiri dengan model diskusi dapat meningkatkan aktivitas dan hasil belajar peserta didik kelas IV Semester Satu Tahun Pelajaran 2018/2019 maka dipandang perlu untuk mengadakan penelitian tindakan kelas (PTK) dengan judul "Upaya Meningkatkan Aktivitas Dan Hasil Belajar Agama Hindu Kelas IV SD Negeri 7 Mataram Dengan Model Inquiri Semester Satu Tahun Pelajaran 2018/2019.

\section{Rumusan Masalah}

Apakah dengan mengoptimalkan penerapan model Pembelajaran Inquiri dapat meningkatkan aktivitas dan hasil belajar Agama Hindu peserta didik kelas IV Semester Satu Tahun Pelajaran 2018/2019 di SD Negeri 7 Mataram?

\section{Tujuan Penelitian}

untuk mengetahui efektifitas penerapan model Pembelajaran Inquiri dalam upaya peningkatan aktivitas dan hasil belajar Agama Hindu peserta didik kelas IV Semester Satu Tahun Pelajaran 2018/2019 di SD Negeri 7 Mataram.

\section{Manfaat Penelitian}

Bagi Peserta Didik : 1) Mendorong peserta didik untuk mengembangkan ketrampilan belajar dalam kelompok (kognitif) dan bersosiolisasi dengan teman dalam proses pembelajaran di kelas senyatanya, 2) Aktivitas belajar Agama Hindu bagi peserta didik dalam upaya pemahaman secara mandiri (eksplorasi) terhadap mata pelajaran Agama Hindu sehingga hasil belajar dapat ditingkatkan.

\section{Bagi Guru Agama Hindu :}

1) Meningkatkan pengembangan pendekatan dan model pembelajaran dengan penerapan model Pembelajaran Inquiri dalam pembelajaran kerja kelompok (kooperatif), 2) Menumbuhkan aspirasi secara ilmiah dalam menjalankan profesi keguruan terutama dalam pengembangan keprofesian berkelanjutan (PKB) bagi guru Agama Hindu.

\section{KAJIAN PUSTAKA Aktivitas}

Aktivitas belajar adalah aktivitas yang bersifat fisik maupun mental. Dalam proses belajar kedua aktivitas itu harus saling berkaitan. Lebih lanjut lagi piaget menerangkan dalam buku Sardiman bahwa jika seorang anak berfikir tanpa berbuat sesuatu, berarti anak itu tidak berfikir (Sardiman, 2011:100).

Nanang Hanafiah dan Cucu Suhana (2010:24) menjelaskan bahwa aktivitas belajar dapat memberikan nilai tambah (added value) bagi peserta didik, berupa halhal berikut ini: 
1. Peserta didik memiliki kesadaran (awareness) untuk belajar sebagai wujud adanya motivasi internal untuk belajar sejati.

2. Peserta didik mencari pengalaman dan langsung mengalami sendiri, yang dapat memberikan dampak terhadap pembentukan pribadi yang integral.

3. Peserta didik belajar dengan menurut minat dan kemampuannya.

4. Menumbuh kembangkan sikap disiplin dan suasana belajar yang demokratis di kalangan peserta didik.

5. Pembelajaran dilaksanakan secara konkret sehingga dapat menumbuh kembangkan pemahaman dan berfikir kritis serta menghindarkan terjadinya verbalisme.

6. Menumbuh kembangkan sikap kooperatif dikalangan peserta didik sehingga sekolah menjadi hidup, sejalan dan serasi dengan kehidupan di masyarakat di sekitarnya.

\section{Jenis-jenis Aktivitas Belajar}

Paul B. Diedrich yang dikutip dalam Nanang hanafiah dan Cucu suhana (2010:24) menyatakan, aktivitas belajar dibagi ke dalam delapan kelompok, yaitu sebagai berikut:

1. Kegiatan-kegiatan visual (visual activities), yaitu membaca, melihat gambar-gambar, mengamati eksperimen, demonstrasi, pameran dan mengamati orang lain bekerja atau bermain.

2. Kegiatan-kegiatan lisan (oral activities), yaitu mengemukakan suatu fakta atau prinsip, menghubungkan suatu kejadian mengajukan pertanyaan, memberi saran, mengemukakan pendapat, berwawancara diskusi dan interupsi

3. Kegiatan-kegiatan mendengarkan (listening activities), yaitu mendengarkan penyajian bahan, mendengarkan percakapan atau diskusi kelompok, atau mendengarkan radio.

4. Kegiatan-kegiatan menulis (writing activities), yaitu menulis cerita, menulis laporan, memeriksa karangan, bahanbahan copy, membuat outline atau rangkuman, dan mengerjakan tes serta mengisi angket.
5. Kegiatan-kegiatan menggambar (drawing activities), yaitu menggambar, membuat grafik, diagram, peta dan pola.

6. Kegiatan-kegiatan motorik (motor activities), yaitu melakukan percobaan, memilih alat-alat, melaksanakan pameran, membuat model, menyelenggarakan permainan, serta menari dan berkebun.

7. Kegiatan-kegiatan mental (mental activities), yaitu merenungkan mengingat, memecahkan masalah, menganalisa faktor-faktor, melihat hubunganhubungan, dan membuat keputusan.

8. Kegiatan-kegiatan emosional (emotional activities), yaitu minat, membedakan, berani, tenang, merasa bosan dan gugup.

Dengan adanya pembagian jenis aktivitas di atas, menunjukkan bahwa aktivitas di sekolah cukup kompleks dan bervariasi. Jika kegiatan-kegiatan tersebut dapat tercipta di sekolah, pastilah sekolahsekolah akan lebih dinamis, tidak membosankan dan benar-benar menjadi pusat aktivitas belajar yang maksimal.

\section{Hasil belajar}

Mukhtar (2003:54) mengatakan bahwa pengertian hasil belajar tidak dapat dipisahkan dan apa yang terjadi dalam aktifitas pembelajaran baik di kelas maupun diluar kelas. Apa yang dialami oleh peserta didik dalam proses pengembangan kemampuannya merupakan apa yang diperoleh dalam belajar dan pengalaman tersebut pada akhirnya dipengaruhi oleh beberapa faktor diantaranya keadaan kognitif, afektif dan psikomotornya pada waktu belajar. Kualitas pengajaran yang diterimanya dan cara pengelolaan proses interaksi yang dilakukan oleh guru.

Masalah evaluasi hasil belajar meliputi alat ukur yang digunakan, cara menggunakan, cara penilaian dan evaluasinya (Harus Rasid dan Mansur, 2008:9). Evaluasi hasil belajar yang berhubungan dengan tugas guru rutin dilakukan evaluasi hasil, yang juga dijadikan umpan balik, evaluasi hasil bertujuan menilai apakah hasil belajar dicapai sesuai dengan tujuan (Lukmanul Hakim, 2008:165).

Pakar pendidikan lain mendefinisikan bahwa yang dimaksud hasil belajar adalah perubahan perilaku secara keseluruhan bukan 
salah satu aspek potensi kemanusiaan saja (Supriyono, 2009:19). Berbeda dengan pendapatnya Bloom (Dalam Sumiati danAska, 2008). Hasil belajar mencakup kemampuan kognitif, afektif, dan psikomotorik. Jadi pendapat ini mengisyaratkan bahwa haasil belajar peserta didik harus diukur dengan tes tertulis, tes sikap, dan kemampuan skil secara nyata selama proses pembelajaran di kelas senyatanya.

Dalam penelitian ini yang dimaksud dengan hasil belajar adalah tes ulangan harian yang dilaksanakan secara tertulis pada akhir pembelajaran dan nilai hasil diskusi kelompok yang dinilai secara perorangan.

\section{Model Pembelajaran Inquiri}

Istilah "inkuiri" berasal dari bahasa Inggris, yaitu inquiry yang berarti pertanyaan atau penyelidikan. Pembelajaran inkuiri adalah pembelajaran yang melibatkan seluruh kemampuan peserta didik secara maksimal untuk mencari dan menyelidiki secara sistematis, kritis, logis, dan analitis, sehingga peserta didik dapat merumuskan sendiri penemuannya dengan penuh percaya diri. Model pembelajaran ini dikembangkan oleh seorang tokoh yang bernama Suchman. Suchman meyakini bahwa anak-anak merupakan individu yang penuh rasa ingin tahu akan segala sesuatu. Teori yang mendasari model pembelajaran inkuiri adalah sebagai berikut :

1. Secara alamiah, manusia mempunyai naluri rasa ingin tahu yang mendorong dirinya menemukan apa yang ingin diketahuinya.

2. Setiap manusia pasti menyadari akan rasa keingintahuannya terhadap segala sesuatu, dan mendorongnya untuk menganalisis secara rasional.

3. Metode atau strategi baru dapat diajarkan secara langsung dan ditambahkan atau digabungkan dengan strategi lama yang telah dimiliki peserta didik.

4. Penelitian kooperatif (cooperative inquiry) dapat memperkaya kemampuan berpikir peserta didik.

\section{Prinsip-prinsip Model Pembelajaran Inkuiri}

1. Berorientasi pada Pengalaman Intelektual

Tujuan utama dari strategi pembelajaran inkuiri adalah pengembangan kemampuan berpikir. Dengan demikian, strategi pembelajaran ini selain berorientasi kepada hasil belajar, juga berorientasi pada proses belajar. Oleh karena itu, kriteria keberhasilan dari proses pembelajaran dengan menggunakan strategi inkuiri bukan ditentukan oleh sejauhmana peserta didik mampu menguasai materi pelajaran, tetapi sejauhmana peserta didik beraktifitas mencari dan menemukan sesuatu.

\section{Prinsip interaksi}

Proses pembelajaran pada dasarnya adalah proses interaksi, baik interaksi antara peserta didik maupun interaksi peserta didik dengan guru, bahkan interaksi antara peserta didik dengan lingkungan sekitarnya. Pendidik atau guru perlu mengarahkan agar peserta didik bisa mengembangkan kemampuan berpikirnya melalui interaksi mereka.

3. Prinsip bertanya

Tugas utama guru atau pendidik dalam menerapkan pembelajaran inkuiri adalah menjadi penanya yang baik bagi peserta didik. Artinya, bagaimana upaya yang harus dilakukan guru agar peserta didik menjadi kritis, kemudian melontarkan pertanyaanpertanyaan tajam. Berbagai jenis dan teknik bertanya perlu dikuasai oleh setiap guru, apakah itu bertanya hanya sekedar untuk meminta perhatian peserta didik, bertanya untuk melacak, bertanya untuk mengembangkan kemampuan, atau bertanya untuk menguji.

4. Prinsip belajar untuk Berpikir

Belajar bukan hanya mengingat sejumlah fakta, tetapi belajar adalah proses berpikir (learning how to think), yakni proses mengembangkan potensi seluruh otak, baik otak kiri maupun otak kanan, baik otak reptile, otak limbic, maupun otak neokorteks.

5. Prinsip Keterbukaan

Belajar adalah suatu proses mencoba berbagai kemungkinan. Segala sesuatu mungkin saja terjadi. Oleh karena itu, anak perlu diberikan kebebasan untuk mencoba 
sesuai dengan perkembangan kemampuan logika maupun nalarnya. Tugas guru adalah menyediakan ruang untuk memberikan kesempatan kepada peserta didik mengembangkan hipotes, dan secara terbuka membuktikan kebenaran hipotesis yang diajukan.

\section{Kerangka Konseptual}

Kerangka konseptual ini menggambarkan hubungan antara variabel tindakan yaitu mengoptimalkan penerapan pendekatan saintifik model pembelajaran inquiri dan variabel harapan adalah meningkatkan aktivitas dan hasil belajar.

\section{Hipotesis Tindakan}

"Jika penerapan Model Pembelajaran Inquiri dilaksanakan secara optimal maka aktivitas dan hasil belajar Agama Hindu peserta didik kelas IV Semester Satu Tahun Pelajaran 2018/2019 dapat ditingkatkan".

\section{METODE PENELITIAN}

\section{Setting Penelitian}

Penelitian tindakan kelas (PTK) ini akan dilaksanakan di kelas IV SD Negeri 7 Mataram Semester Satu Tahun Pelajaran 2018/2019, dengan jumlah peserta didik sebanyak 8 orang.

\section{Faktor yang Diteliti}

- Faktor Guru: yaitu dengan mengganti cara guru membuat Rencana Pelaksanaan Pembelajaran (RPP) dan pelaksanaannya dalam pembelajaran di kelas senyatanya dengan menerapkan pendekatan saintifik model Pembelajaran Inquiri dalam upaya meningkatkan aktivitas dan hasil belajar Agama Hindu peserta didik Kelas IV SD Negeri 7 Mataram.

- Faktor Peserta Didik: yaitu peningkatan aktivitas dan hasil belajar yang terlihat pada perilaku peserta didik selama diskusi kelompok, yang berdampak pada peningkatan aktivitas dan hasil belajar Agama Hindu peserta didik Kelas IV Semester Satu Tahun Pelajaran 2018/2019 di SD Negeri 7 Mataram.

\section{Rencana Tindakan}

Tindakan nyata yang dilakukan oleh guru selaku peneliti adalah dengan menggunakan siklus. Gambaran siklus dalam penelitian ini adalah sebagai berikut:

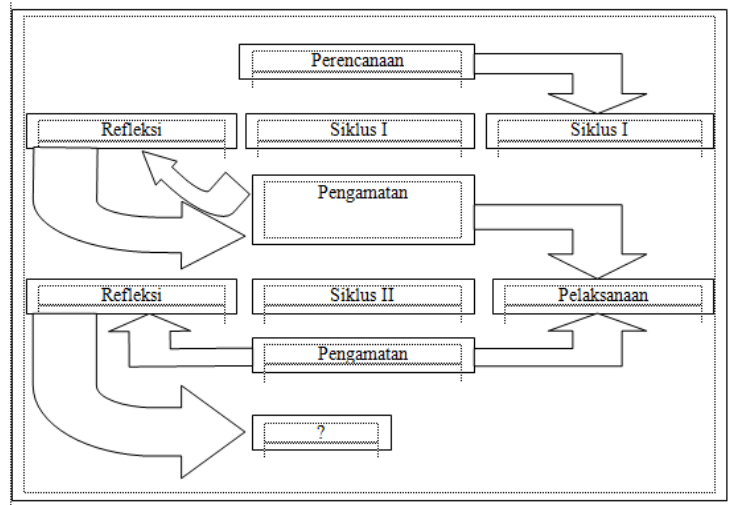

Setiap siklus selama penelitian ini berisi 4 (empat) tahapan yaitu: 1) Perencanaan (Planning), 2) Pelaksanaan (Action), 3) Observasi (Observation), dan 4) Refleksi (Reflection).

\section{Siklus Tindakan}

\section{SIKLUS I}

\section{Tahap Perencanaan (Planning)}

Pada tahapan ini guru selaku peneliti melakukan kegiatan-kegiatan sebagai berikut:

1. Menyusun Rencana Pelaksanaan Pembelajaran (RPP) dengan skenario sesuai dengan aturan main model pembelajaran saintifik model Pembelajaran Inquiri

2. Menyiapkan sumber, bahan, dan semua alat yang digunakan dalam penelitian.

3. Menyusun/membuat lembar observasi guru dan lembar observasi peserta didik.

4. Menyusun alat evaluasi.

\section{Tahap Pelaksanaan (Action)}

Pada tahapan ini guru selaku peneliti melaksanakan proses pembelajaran dengan penerapan pendekatan pembelajaran saintifik model Pembelajaran Inquiri dengan skenario sebagai berikut :

\section{Pertemuan I}

1. Guru membagi peserta didik menjadi 4 (empat) kelompok kecil, masing-masing kelompok beranggotakan 2 orang peserta didik.

2. Masing-masing kelompok diberikan tugas/soal untuk dipecahkan bersama dalam kelompok, selanjutnya guru berkeliling untuk membimbing kelompok utamanya yang mengalami kesulitan/permasalahan.

\section{Pertemuan II}


3. Masing-masing kelompok maju kedepan untuk mempresentasikan hasil kerja kelompok secara bergiliran.

4. Tes tertulis

\section{Tahap Observasi (Observation)}

Pada tahapan observasi ini diadakan pengamatan oleh observer untuk mengamati :

1. Observasi guru :

Dilakukan oleh pembimbing mata pelajaran Agama Hindu observer sekaligus sebagai pembimbing guru dalam melaksanakan Penelitian Tindakan Kelas (PTK).

2. Observasi Peserta Didik :

Dilaksanakan oleh guru mata pelajaran sekaligus sebagai peneliti dalam Penelitian Tindakan Kelas (PTK) pada kegiatan diskusi kelompok.

\section{Tahap Refleksi (Reflection)}

Pada tahapan ini guru selaku peneliti melakukan kegiatan akhir dari hasil penelitian pada siklus yang bersangkutan meliputi :

1. Renungan hasil perolehan data

2. Pengolahan dan analisa data hasil penelitian

3. Mencocokkan hasil analisa data dengan indikator keberhasilan

4. Rencana perbaikan dan tindak lanjut

\section{SIKLUS II}

Pada siklus ini semua kegiatan dan tahapan selama penelitian adalah sama, sifatnya mengulang dan memperbaiki terhadap tindakan yang masih memerlukan penyempurnaan dan pembenaran sebagaimana mestinya.

\section{Data dan Cara Pengambilannya. \\ Sumber Data}

Yang menjadi sumber data dalam penelitian tindakan kelas (PTK) ini adalah semua peserta didik kelas IV Semester Satu Tahun Pelajaran 2018/2019 di SD Negeri 7 Mataram dan peneliti.

\section{Jenis Data}

- Jenis data yang berasal dari guru selaku peneliti
1) Data tentang Rencana Pelaksanaan Pembelajaran (RPP)
2) Data Pelaksanaan Pembelajaran

- Jenis data yang berasal dari peserta didik :

1) Data kemajuan aktivitas belajar
2) Data hasil diskusi kelompok

3) Data hasil belajar

Cara Pengambilan data

- Data kegiatan pembelajaran diambil dari RPP yang dibuat oleh guru dan lembar observasi pelaksanaan metode pembelajaran model Pembelajaran Inquiri

- Data kemajuan aktivitas belajar; diambil dari lembar observasi selama diskusi kelompok.

- Data kemajuan hasil belajar; diambil dari laporan individu hasil diskusi kelompok dan hasil tes tertulis yang dilaksanakan pada akhir proses pembelajaran

Indikator Keberhasilan dan Teknik analisa data

\section{Teknik analisa data}

Untuk menganalisis data akan dilakukan melalui analisis deskriptif kuantitatif melalui pendataan, analisis dan pembahasan terhadap data yang diperoleh dengan mencocokkan tingkat keoptimalan terhadap capaian indikator keberhasilan yang ada.

\section{Indikator Keberhasilan}

- guru telah dinyatakan berhasil melaksanakan proses pembelajaran dengan pendekatan saintifik model Pembelajaran Inquiri, bila telah mencapai skor rata-rata $\geq 4,00$ (kategori baik)

- Aktivitas belajar Agama Hindu peserta didik kelas IV dinyatakan telah meningkat jika $85 \%$ dari jumlah peserta didik telah memperoleh skor rata-rata $\geq$ 4,0 dan hasil belajar dinyatakan telah meningkat jika $85 \%$ dari jumlah peserta didik memperoleh nilai rata-rata $\geq 75,00$ (sesuai KKM).

\section{HASIL DAN PEMBAHASAN \\ DESKRIPSI SIKLUS I}

Tahap Perencanaan

Pada tahapan ini yang telah dilakukan oleh guru selaku peneliti adalah; 1) menyusun RPP dengan skenario pembelajaran model Pembelajaran Inquiri, 2) telah berhasil menyiapkan alat, sumber, bahan yang diperlukan dalam penelitian, 3) berhasil menyusun instrument observasi guru dan instrument observasi peserta didik, dan 4) menyusun alat evaluasi. 


\section{Tahap Pelaksanaan}

Pada tahap pelaksanaan proses pembelajaran dengan pendekatan saintifik model Pembelajaran Inquiri ini yang dilakukan oleh guru adalah

\section{Pertemuan Pertama:}

1. Guru menyampaikan materi pelajaran dengan pendekatan saintifik dengan kegiatan mengamati dan menanya

2. Peserta didik dibagi menjadi 4 kelompok kecil yang anggotanya 2 orang peserta didik secara heterogen

3. Peserta didik berdiskusi dengan model Pembelajaran Inquiri dengan kegiatan pokoknya memecahkan persoalan/soalsoal yang menjadi tanggung jawabnya.

4. Selama peserta didik berdiskusi, guru berkeliling membimbing kelompok sekaligus melakukan observasi/pengamatan terhadap aspekaspek yang telah direncanakan.

\section{Pertemuan kedua}

1. Masing-masing kelompok secara bergiliran mempresentasikan di depan kelas yang diikuti oleh semua anggota kelompok.

2. Guru mengamati/mengobservasi ketrampilan peserta didik selama persentasi sesuai dengan aspek pengamatan ketrampilan yang telah di rencanakan.

\section{Tes tertulis}

\section{Tahap Observasi}

Observasi guru guru memperoleh skor ratarata pertemuan I $(3,29)$ dan pertemuan II $(3,36)$, observasi peserta didik memperoleh skor rata-rata pertemuan I $(3,38)$ dan pertemuan II $(3,63)$, perolehan hasil belajar dalam bentuk tugas dan tes memperoleh nilai rata-rata sebesar $(66,25)$ dan $(71,25)$.

\section{Tahap Refleksi}

Pada tahapan ini peneliti melakukan kegiatan refleksi sebagai dampak dari perolehan data hasil observasi guru, observasi peserta didik (diskusi kelompok dan presentasi), serta rata-rata nilai tes tertulis sebagai berikut:

1. Renungan data hasil perolehan data pada siklus I
2. Pengolahan data hasil observasi guru, peserta didik dan tes tertulis.

3. Mencocokkan hasil yang ada dengan Indikator keberhasilan.

4. Merencanakan perbaikan terhadap jenis tindakan yang menyebabkan belum tuntas Indikator keberhasilan. Oleh karena Indikator keberhasilan belum terbukti maka penelitian dilanjutkan ke siklus II.

\section{DESKRIPSI SIKLUS II}

\section{Tahap Perencanaan}

Pada tahapan ini jenis kegiatan yang dilakukan masih mengacu pada kegiatan siklus I, bedanya hanya terjadi perbaikan seperlunya yaitu: 1) penyusunan RPP dengan mengacu pada pendekatan saintifik model Pembelajaran Inquiri dan diskusi kelompok dan penyempurnaan pada bagian skenario pembelajaran, 2) menyiapkan alat, sumber, bahan yang diperlukan dalam proses tindakan dikelas senyatanyan, 3) menyiapkan lembar observasi guru dan lembar observasi peserta didik sebagaimana pada siklus I, 4) menyiapkan alat evaluasi sebagaimana yang telah dibuat pada siklus I.

\section{Tahap Pelaksanaan}

Secara umum tahapan pelaksanaan proses pembelajaran pada siklus II ini masih mengacu pada pelaksanaan proses pembelajaran sebelumnya. Pemecahan yang dilakukan pada proses pembelajaran ini adalah: 1) pelaksanaan proses diskusi kelompok kecil lebih dioptimalkan, 2) pelaksanaan pembimbingan kelompok sekaligus observasi peserta didik lebih di efektifkan. Utamanya pengamatan peserta didik yang aktif, yang kurang aktif, peserta didik yang tidak aktif, dengan harapan proses analisa data lebih signifikan, 3) laporan hasil kerja kelompok yang dibuat secara individu yang dipresentasikan dikelas difokuskan, dan 4) pelaksanaan tes tertulis sebagai perwujudan dari peningkatan hasil belajar peserta didik lebih diperketat.

\section{Tahap Observasi}

Observasi guru guru memperoleh skor ratarata pertemuan I $(4,36)$ dan pertemuan II $(4,57)$, observasi peserta didik memperoleh skor rata-rata pertemuan I $(4,25)$ dan 
pertemuan II $(4,63)$, perolehan hasil belajar dalam bentuk tugas dan tes memperoleh nilai rata-rata sebesar $(77,00)$ dan $(80,00)$.

\section{Tahap Refleksi}

Jenis kegiatan yang dilakukan oleh peneliti pada tahapan ini sama dengan apa yang dilakukan pada siklus I, adalah sebagai berikut:

1. Renungan atas perolehan data hasil observasi guru, observasi peserta didik, dan hasil tes tertulis sebagai wujud dari peningkatan aktivitas dan hasil belajar peserta didik di kelas senyatanya.

2. Pengolahan data hasil observasi guru, observasi peserta didik, presentasi peserta didik dan tes tertulis

3. Mencocokkan perolehan data hasil tindakan dengan Indikator keberhasilan yang telah ditetapkan.

4. Guru memberikan hadiah/reward kepada semua peserta didik kelas IV atas keberhasilannya dalam upaya meningkatkan motivasi belajar yang berdampak terhadap perolehan hasil belajar sesuai dengan KKM yang telah ditetapkan.

\section{PEMBAHASAN}

\section{SIKLUS I}

\section{Tahap Perencanaan}

Peneliti menyusun RPP dengan skenario penerapan pendekatan Saintifik model Discovery Learning, menyiapkan alat, sumber, bahan yang diperlukan dalam proses pembelajaran, menyiapkan instrument observasi guru maupun instrument observasi peserta didik. Ada kendala yang dihadapi selama persiapan alat dan bahan pembelajaran, tetapi setelah meminta petunjuk kepada pembimbing kendala yang dihadapi pun dapat diatasi dengan baik.

\section{Tahap Pelaksanaan}

\section{Pertemuan I}

a. Mengamati

- Guru menugaskan kepada peserta didik secara berkelompok untuk menggali informasi dari buku paket tentang materi pelajaran yang disajikan.
- Guru menjelaskan materi pelajaran dan memberikan contoh konkrit yang bisa dimengerti oleh peserta didik

b. Menanya

- Guru memberikan trik-trik kepada peserta didik tentang tata cara bertanya yang baik dan benar sesuai dengan materi pelajaran yang sedang disajikan.

- Peserta didik secara teratur bertanya tentang hal-hal yang belum dimengerti sesuai materi yang sedang dipelajari.

c. Mencoba (mengumpulkan data/informasi)

- Secara berkelompok peserta didik mendiskusikan masalah yang menjadi tanggung jawabnya.

- Melakukan eksperimen dalam kelompok terhaadap permasalahan yang sedang di diskusikan

- Mengumpulkan data yang berasal dari semua anggota kelompok

d. Mengasosiasikan/mengolah informasi

- Semua anggota kelompok menjawab dan menelaah semua jawaban yang telah di diskusikan bersama

- Hasil jawaban di analisis bersama untuk bisa di paparkan di depan kelas pada saat menyampaikan informasi

- Kelompok membuat kesepakatan akhir dari hasil diskusi kelompok

\section{Pertemuan II}

e. Mengkomunikasikan

1. Guru kembali menyampaikan uraian materi pelajaran terkait dengan hasil kegiatan mengamati, menanya, mencoba, dan mengolah informasi.

2. Guru mempersilahkan kepada semua anggota kelompok untuk menginformaasikan hasil kerja kelompoknya.

3. Semua peserta didik secara berkelompok menanggapi setiap paparan dari kelompok lain

4. Peserta didik dengan bimbingan guru membuat kesimpulan bersama dari seluruh permasalahan/soal yang menjadi tanggung jawabnya.

5. Tes tertulis.

\section{Tahap Observasi}


Observasi guru pertemuan I memperoleh skor rata-rata 3,29 dan pertemuan II memperoleh skor rata-rata 3,36, sementara Indikator keberhasilan yang diharapkan $(\geq 4,0)$, Hasil observasi peserta didik dalam upaya peningkatan aktivitas dan hasil belajar Agama Hindu peserta didik kelas IV Semester Satu Tahun Pelajaran 2018/2019 di SD Negeri 7 Mataram diperoleh skor ratarata pertemuan I $(3,38)$ dan pertemuan II $(3,63)$. Indikator keberhasilan $(\geq 4,0)$, Dari nilai tugas dan hasil tes tertulis yang materinya hanya sekitar yang diajarkan pada saat itu juga, diperoleh nilai rata-rata $(66,25)$ dan $(71,25)$ kategori cukup.

\section{Tahap Refleksi}

Hasil analisa data peningkatan motivasi belajar pada siklus I ini $(3,51)$ sedangkan yang diminta dalam Indikator keberhasilan $(\geq$ 4,0), ini artinya belum berhasil. Karena Indikator keberhasilan belum tercapai, penelitian tindakan kelas (PTK) dilanjutkan ke siklus II dengan harapan optimalisasi penerapan strategi pembelajaran dengan pendekatan saintifik model Pembelajaran Inquiri dapat meningkatkan aktivitas belajar Agama Hindu peserta didik kelas IV Semester Satu Tahun Pelajaran 2018/2019 di SD Negeri 7 Mataram.

\section{SIKLUS II}

\section{Tahap Perencanaan}

Peneliti menyusun Rencana Pelaksanaan Pembelajaran (RPP) dengan memperhatikan kesalahan-kesalahan pada siklus I. peneliti lebih memfokuskan tentang Rencana strategi jitu sehingga proses pembelajaran dengan pendekatan Saintifik model Pembelajaran Inquiri dapat terelaisasi dengan baik, karenanya dalam penyusunan skenario benar-benar dirinci dari tiap aspek pada proses pembelajaran dengan model Pembelajaran Inquiri.

Sebelum proses pembelajaran dilaksanakan, peneliti menyiapkan semua alat, bahan, dan segala sesuatunya sehingga dalam pelaksanaan proses pembelajaran berjalan sesuai dengan skenario yang telah direncanakan. Agar proses pembelajaran dapat teratasi maka peneliti juga menyiapkan lembar observasi guru dan lembar observasi peserta didik sebagai tolak ukur ketercapaian peningkatan aktivitas dan hasil belajar Agama Hindu peserta didik kelas IV SD Negeri 7 Mataram.

\section{Tahap Pelaksanaan}

Pada tahap pelaksanaan di siklus II ini pada dasarnya masih mengacu pada pelaksanaan siklus I, yaitu penerapan pendekatan Saintifik model Pembelajaran Inquiri dan. Bedanya pada siklus ini lebih dioptimalkan.

\section{Tahap Observasi}

Pada siklus II ini hasil observasi pertemuan pertama skor rata-rata $(4,36)$ dan pertemuan kedua $(4,57)$ sementara Indikator keberhasilan yang diharapkan $(\geq 4,0)$, Upaya meningkatkan aktivitas belajar Agama Hindu peserta didik kelas IV Semester Satu Tahun Pelajaran 2018/2019 di SD Negeri 7 Mataram pada pertemuan I diperoleh skor rata-rata $(4,25)$ dan pertemuan II $(4,63)$, sementara Indikator keberhasilan yang telah diharapkan adalah $(\geq 4,0)$, Dampak nyata dari meningkatnya motivasi belajar adalah hasil belajar juga meningkat, dari data nilai tugas dan hasil perolehan nilai rata-rata tes tertulis adalah $(77,00)$ dan $(80,00)$ sementara pada siklus sebelumnya hanya $(66,25)$ dan $(71,25)$ berarti mengalami peningkatan yang signifikan.

\section{Tahap Refleksi}

Hasil analisa data peningkatan aktivitas dan hasil belajar peserta didik pada siklus II adalah $(4,25)$ dan $(78,50)$ sedangkan Indikator keberhasilan $(\geq 4,0)$ dan $\geq 75,00$. Ini artinya pada siklus II hasilnya telah melampaui Indikator keberhasilan yang telah di tetapkan. Karena Indikator keberhasilan telah terbukti, maka tidak perlu ada upaya perbaikan dan penyempurnaan. Pendekatan Saintifik model Pembelajaran Inquiri telah mampu meningkatkan aktivitas dan hasil belajar peserta didik yang ditandai dengan tercapainya Indikator keberhasilan dan terjadinya peningkatan hasil belajar peserta didik. "Penelitian Tindakan Kelas (PTK) dihentikan pada siklus II dengan hasil memuaskan."

\section{SIMPULAN}


Data komulatif dari hasil penelitian tindakan kelas (PTK) dari siklus I ke Siklus II adalah sebagai berikut:

\begin{tabular}{|c|c|c|c|c|c|c|c|}
\hline \multirow{2}{*}{$\mathrm{N}_{0}$} & \multirow{2}{*}{ Jenis Kegiatan } & \multirow{2}{*}{$\begin{array}{c}\text { Indikator } \\
\text { keberhasilan }\end{array}$} & \multicolumn{2}{|c|}{ Siklus I } & \multicolumn{2}{|c|}{ Siklus II } & \multirow[t]{2}{*}{ Keterangar } \\
\hline & & & I & II & I & II & \\
\hline 1. & Observasi Guru & $\geq 4,00$ & 3,29 & 3,36 & 4,36 & 4,57 & Meningkat \\
\hline 2. & Observasi Peserta didik & $\geq 4,00$ & 3,38 & 3,63 & 4,25 & 4,63 & Meningkat \\
\hline 3. & Tugas individual & $\geq 75,00$ & \multicolumn{2}{|c|}{66,25} & \multicolumn{2}{|c|}{77,00} & Meningkat \\
\hline 4. & Tes tertulis & $\geq 75,00$ & \multicolumn{2}{|c|}{71,25} & \multicolumn{2}{|c|}{80,00} & Meningkat \\
\hline
\end{tabular}

Penerapan pendekatan Saintifik model Pembelajaran Inquiri sangat efektif upaya untuk meningkatkan aktivitas dan hasil belajar Agama Hindu peserta didik kelas IV Semester Satu Tahun Pelajaran 2018/2019 di SD Negeri 7 Mataram. Fakta telah menunjukkan perolehan rata-rata skor motivasi belajar peserta didik pada siklus I ke siklus II sudah melampaui Indikator keberhasilan yang ditetapkan. Penelitian dinyatakan "berhasil" dan dihentikan pada siklus II.

\section{SARAN}

Disarankan kepada guru sejawat untuk melaksanakan Penelitian Tindakan Kelas (PTK) dalam upaya untuk meningkatkan aktivitas dan hasil belajar peserta didik sesuai dengan mata pelajaran masing-masing.

Disarankan kepada para semua peserta didik kelas IV SD Negeri 7 Mataram untuk membiasakan belajar dengan pendekatan yang kontekstual utamanya strategi yang mampu membangkitkan motivasi belajar peserta didik yang dampaknya hasil belajar dapat ditingkatkan seperti yang diharapkan.

\section{DAFTAR PUSTAKA}

Anonim, 2018, dalam http://desialuthfil1.blogspot.com/2017 107/makalah-model-pembelajaraninkuiri.html, tanggal 20 September 2018, pukul 16.46 Wita.

Anonim, 2018, dalam https://www.kajianpustaka.com/2014/ 06/pengertian-dan-jenis-aktivitasbelajar.html tanggal 20 September 2018, pukul 20.30 Wita.

Arikunto, s. 2009, Penelitian Tindakan Kelas, Jakarta : Bumi Aksara.

Harun Rasyid dan Mansur, 2008, Penilaian Hasil Belajar, Bandung : CV Wacana Prima.
Lukmanul A, 2008, Perencanaan Pembelajaran, Bandung : CV Wacana Prima. Mukhtar, 2003, Prosedur Penilaian, Jakarta : Rineka Cipta.

Nurhadi, 2003, Yasin ,B dan Sendule.A, 2003, Kontekstual dan Penerapannya dalam KBK, Malang : Unitipetas Negeri Malang.

Robert E Slavin, 2010, Cooperative Learning Teori, riset dan Praktik, Bandung : Nusa Media.

Sardiman, 2007, Indikator Dan Motivasi Belajar Mengajar, Jakarta : Raja Grafindo Perkasa.

Supriono, 2009, Cooperative Learning Teori dan Aplikasi PAIKEM, Yogyakarta : Pustaka Pelajar.

Permen 81A Tahun 2013 Tentang Implementasi Kurikulum 2013 